2017-05

\title{
Strandings of NE Atlantic gorgonians
}

\author{
Sheehan, Emma
}

http://hdl.handle.net/10026.1/12885

10.1016/j.biocon.2017.03.020

Biological Conservation

Elsevier BV

All content in PEARL is protected by copyright law. Author manuscripts are made available in accordance with publisher policies. Please cite only the published version using the details provided on the item record or document. In the absence of an open licence (e.g. Creative Commons), permissions for further reuse of content should be sought from the publisher or author. 
Strandings of NE Atlantic gorgonians

Sheehan EV*, Rees A., Bridger D, Williams T, Hall-Spencer JM

School of Biological and Marine Sciences, Marine Institute, University of Plymouth, Plymouth, Drake Circus, PL4 8AA, UK.

*Corresponding author: Dr Emma Sheehan emma.sheehan@plymouth.ac.uk; Tel. 0044

(0)1752 584699; Fax. 0044 (0) 1752584950

\section{Abstract}

1. Northeast coral gardens provide vital breeding and feeding habitats for fishes of conservation and commercial importance. Such habitats are increasingly at risk of destruction as a result of over fishing, surface ocean warming, acidification and marine litter.

2. A key cause for concern regarding the vulnerability of coral gardens to damage from any source is their slow growth rate, and thereby their ability to recover from damage. Hence protected areas are being put in place, which exclude the use of towed demersal fishing gear.

3. Citizen scientists observed that gorgonian corals (Pink Sea Fans) skeletons were stranding on beaches entangled in marine debris (sea fangles) across southwest England. Further, SCUBA divers reported that gorgonian corals were being caught up and damaged in lost fishing gear and other marine litter.

4. To determine the cause of the damage to coral gardens, sea fangles were collected and analysed.

5. The sea fangles were made up of a diverse range of litter from fishing and domestic sources, however, the majority comprised of fishing gear $(P<0.05)$.

6. Marine Protected Areas can protect coral gardens from direct fishing pressure, but risks still remain from ghost fishing pressure, demonstrating the need for sources of litter into the environment to be reduced and existing litter removed.

7. The EU MSFD outlines targets for marine litter by 2020. This study highlights the importance of adhering to the MSFD and/or creating more ambitious regulation if the UK re-write existing legislation following BREXIT.

Keywords: Coral, reef, benthic, conservation, marine litter, ghost fishing 
The northeast Atlantic has a highly diverse coral fauna (Roberts et al., 2009), and historical records show that the region used to have extensive scleractinian coral reefs, as well as gardens of cold-water alcyonaceans (leather corals), antipatharians (black corals), gorgonians (sea fans) and stylasterids (hydrocorals) (Hall-Spencer et al. 2007b). Drawings by Gosse (1860) brought international attention to the beauty and abundance of anthozoans in the region and cold-water corals have long fascinated marine biologists due to the high diversity of life associated with the habitats that they create (Le Danois, 1948). In this paper, evidence of recent damage to coral gardens globally is discussed, prompted by citizen scientist reports of strandings of gorgonians in southwest England in late 2014.

In shallow waters above the thermocline there have been increasing incidences of gorgonian disease in tropical and temperate waters (Hall-Spencer et al. 2007a; Kim, 2015), and marine heat waves have caused mass mortalities in gorgonian populations (Cerrano et al. 2000). The combined effects of stressors such as over-fishing, surface ocean warming, acidification and marine litter mean that the managers of maritime activities will need to be forward-thinking to protect cold-water coral habitats (Witherell \& Coon, 2000; Bo et al. 2014; Jackson et al. 2014).

Where strong currents and hard substrata are available, gorgonians can form dense stands from shallow waters down to depths of $>2000 \mathrm{~m}$ (coral gardens) (Yesson et al. 2012). These coral gardens increase habitat structural complexity and thereby contribute strongly to their biodiversity (Krieger \& Wing, 2002; Ponti et al. 2016). Cold-water corals that are easily damaged by towed demersal fishing gear provide habitat for the feeding and breeding of commercially important fishes (Costello et al. 2005). The mounting evidence of impacts of bottom trawling on scleractinians shows that towed demersal fishing leaves behind smashed reef frameworks (Hall-Spencer et al. 2002; Clark et al. 2010). Fishing impacts on gorgonians have a less obvious legacy, although gorgonians are just as vulnerable to the use of towed demersal gear and can be a prominent component of the by-catch (Watling \& Norse, 1998; Stone, 2006; Edinger et al. 2007; Bo et al. 2014). A main reason for concern over the vulnerability of coral gardens to damage from any source is their slow rate of growth, so protected areas are being put in place, which exclude the use of towed demersal fishing gear (Althaus et al. 2009; Hall-Spencer et al. 2009; Harter et al. 2009; Sheehan et al. 2013a\&b).

There are 83 species of gorgonian corals described for the NE Atlantic, but the vast majority of these live below $200 \mathrm{~m}$ depth (Hall-Spencer et al. 2007b). Only one species, Eunicella verrucosa (Pallas, 1766), occurs in shallow waters off England. It is known locally as the 'Pink Sea Fan' and large colonies may be over 50 years old: although they may grow up to $10 \mathrm{~cm}$ in the first year, their growth rate then slows to around $1 \mathrm{~cm}$ per year (Wood, 2013). This species is characteristic of rocky reefs on open coasts, although the rock substrata may not always be obvious due to a thin sediment veneer (Sheehan et al. 2013b), where it provides habitat for 
nilsohdneri (Marcus Ev. 1983) and the gastropod Simnia hiscocki (Pennant 1777) (Wood, 2013) as well as three dimensional seabed structures within which fish shelter (Figure 1). In the 1960s-70s, E. verrucosa were collected for souvenirs and so this is now one of the few marine species protected from intentional damage (Wildlife and Countryside Act, 1981). It is also listed as 'Nationally Scarce' in the UK and listed as 'Vulnerable' on the International Union for Conservation of Nature and Natural Resources 'Red List' of threatened species (IUCN, 2015). Heavy demersal gear types, such as beam trawls and scallop dredges, are currently widely used in southwest England (Campbell et al. 2014) and so there have recently been localized bans on their use over coral gardens within key conservation areas of the region (Sheehan et al. 2013, Pikesley et al. 2016). Eno et al. (2001) found that E. verrucosa were resilient to potting so this, and other forms of static gear, are currently permitted within coral gardens off southwest England.

While exclusion of demersal towed gear has benefitted Pink Sea Fan populations (Sheehan et al. 2013a\&b), dead Pink Sea Fans are still stranding around southwest England, entangled in marine debris, from here on referred to as sea fangles. A 'fangle' is something newly fashioned or a foolish innovation. It is suspected that protected Pink Sea Fans are still being fished through the process of ghost fishing. Ghost fishing is the process of marine organisms becoming entangled in lost fishing gear and is most commonly associated with birds and cetaceans (Matsuoka et al. 2005; Brown \& Macfadyen, 2007). It appears, however, that Pink Sea Fans are not only being ghost fished by lost fishing gear but also by domestic marine litter. The present study arose when hundreds of sea fangles were washed up on strandlines at multiple locations around southwest England in the winter of 2014-15, a phenomenon first reported in 2006 (unpublished data). It should be noted, that sea fangle strandings are now observed every winter in southwest England. The 2016 sea fangle strandings have been observed from November around the north and south coast of Cornwall, southwest England (TW and EV pers. obs.). To identify the source and scale of the marine debris entangled around the Pink Sea Fans, sea fangles were collected from three locations (Newquay, Wembury, Chesil see Figure 2.) and analysed. It is impossible to determine from the stranded sea fangles whether they were ghost fished, or broken off by fishing, storms and/or SCUBA divers (Coma et al. 2004), however, the hypothesis that the majority of the source of the entangled debris was from fishing was tested. To provide further evidence to test whether the cause of the stranded sea fangles was ghost fishing, observations made by Seasearch SCUBA divers (a UK based organisation, which uses volunteers to survey sub-tidal habitats) of living sea fans entangled with marine debris are also included. An animation demonstrating the ghost fishing hypothesis can be viewed at https://www.youtube.com/watch?v=n9SsNb6ck7g 
114 In 2014, local naturalists and beachcombers sent in reports to Plymouth University of 115 hundreds of washed-up Pink Sea Fans around southwest England. In response, bundles of 116 marine debris entangled around Pink Sea Fans (sea fangles) were collected systematically 117 from the strandline at each of the reported locations: Chesil Beach, Wembury and Newquay 118 (Figure 2). The rocky reef habitats off each of these beaches have gardens of $E$. verrucosa 119 coral colonies in the circalittoral zone at depths of $>20 \mathrm{~m}$ (Pikesley et al. 2016), although the 120 stranded skeletons could have come from farther afield. Sea fangles were collected in January and February 2015, and processed at Plymouth University on $9^{\text {th }}$ March 2015. To assess the nature and variety of the sea fangles, sea fangles with a minimum of one sea fan amongst a tangled pile of marine litter were selected (Chesil Beach $n=30$, Wembury $n=15$ and Newquay $\mathrm{n}=30$ ). Each sea fangle was photographed, weighed, measured (length and width) and dissected so that each entangled gorgonian and pieces of marine debris could be measured and identified. If there was a central gorgonian skeleton that the rest of the bundle was tangled around, then its length and width was measured and any peripheral gorgonians were counted and weighed. It was also noted whether holdfasts were present (Table S1 in the supporting information lists of the metrics taken to describe to nature of the sea fangles).

\section{Data analysis}

132 For each location and each metric the mean, standard deviation, maximum value and minimum value were calculated and summarised in Table S1. The measured debris were grouped into two source categories 'Fishing' or 'Domestic'. A two-factor Permutational Multivariate Analysis of Variance (PERMANOVA+) in the software package PRIMER v6 (Anderson 2001; Clarke \& Warwick 2001) was used to compare the fixed factors Source (Fishing or Domestic) and Location (Chesil Beach, Wembury or Newquay). To ensure data independence for the analysis, the Fishing debris data was used from half of the sea fangles, and the Domestic data was used from the remaining gorgonians. Data were untransformed and based on Euclidean distance. To assess which fishing gear types entangled the seafans in each location the mean and standard deviation of each fishing gear type for the three locations were plotted on a bar chart.

\section{Results}

144 During the surveys in 2015, hundreds of strandings of Eunicella verrucosa were observed at each location investigated around southwest England. Almost all of the tangled bundles of marine debris contained a central dead, black or brownish skeletal remains of $E$. verrucosa

147 (Chesil Beach $=83 \%$, Wembury $=86 \%$, Newquay $=90 \%$ ). The sea fangles were made up of a 
diverse array of marine litter from fishing and domestic sources (Figures 3 ) and most of the gorgonians still had a holdfast (Chesil Beach $=76 \%$; Wembury $=100 \%$; Newquay $=52 \%$ ).

\section{Sea fangle size and composition}

The weight of each sea fangle varied from $12.2-819.2 \mathrm{~g}$, and their size varied from 12.0 - 77.5 $\mathrm{cm}$ long and $6.0-43.0 \mathrm{~cm}$ wide. The height of the central gorgonian within the sea fangle of marine litter varied from $7.5-27.2 \mathrm{~cm}$. In addition to the central gorgonian, up to 46 additional small gorgonians were found within the sea fangles (see supporting information Table S1 for sea fangle metrics). There was a wide variety of domestic items found tangled around the gorgonians (i.e. balloons, tights, clothes, plastics, metals and glass fragments), although the amount of debris from fishing was significantly greater than from a domestic source (Figure 4: $\mathrm{P}<0.05$; Table 1 ).

While a significant Source $x$ Location was detected, this was a result of the magnitude of difference between debris Source at each Location rather than direction of differences. The amount of fishing vs. domestic debris in the sea fangles was consistently significantly greater at each Location (Wembury, Newquay, and Chesil Beach (Figure 4: $\mathrm{P}<0.05$; Table 1).

At all sites, the following categories of fishing debris were observed; Monofilament, Gill net (fine), Trawl net (thick), Fishing line (other) and Rope. Similar lengths of each fishing debris source were observed entangled in the Chesil Beach sea fangles, Gill net was the most abundant category in the Wembury sea fangles, while Monofilament was most abundant in sea fangles washed up at Newquay (Figure 4).

\section{Evidence of 'Ghost Fishing'}

Over the past decade, divers have often encountered plastic fishing gear amongst living coral gardens on rocky reefs off coasts of southwest England (Dr Keith Hiscock and Chris Wood Seasearch pers. comm.; ES \& JHS pers. obs.). Fishing line and other marine debris such as plastic bags have become snagged and subsequently overgrown by $E$. verrucosa (see Figure 6). Evidence of $E$. verrucosa overgrowing fishing line was also observed during the sea fangles analysis (Figure 3e). When colonies are broken, e.g. through being severed by fishing line, the corals then lay flat on the seafloor and eventually die; the pink or white outer coenenchyme rots leaving the black internal skeleton visible. 
181 Demersal trawls and dredges have well documented major adverse impacts on long-lived sessile organisms (Rinsjorp et al. 2016). Damage to corals by towed demersal gear has expanded enormously over the past 100 years, substantially altering benthic habitats (Koslow et al. 2001). Trawling damages coral gardens by reducing the complexity of habitats that they provide to fishes for feeding, breeding and shelter (Mortensen et al. 2005; Söffker et al. 2011; Sheehan et al. 2013). Fishing lines and gill nets also cause damage to deep water gorgonians by abrasion, they can rip the colonies from the seabed or ensnare them when gear is lost or it has been abandoned (Mortensen et al. 2005; Bo et al. 2014; Lastras et al. 2016). However, this effect has not been documented for the shallow water and protected species Eunicella verrucosa.

The reason why the gorgonian $E$. verrocosa can be found in high abundances off southwest England is that it grows on rocky reefs, many of which are inaccessible to towed demersal gear (Hinz et al. 2011; Pikesley et al. 2016). Even on reefs that are heavily impacted by towed demersal gear, e.g. on low lying mudstone, there can be crevices within the complex rocky habitats in which gorgonians persist (Hinz et al. 2011) just as patches of gorgonians can still be found in inaccessible rocky canyons off Maine (Auster et al. 2013). Further, E. verrucosa can also grow on lower lying rock covered in a sediment veneer when the habitat is protected from demersal towed gear (Sheehan et al. 2013b). If such areas can be protected effectively, then the corals that survived fishing gear impacts in refugia can provide brood stock for the recovery of coral gardens (Pikesley et al. 2016).

Pink Sea Fans entangled with marine debris described here could have formed after gorgonians were detached from the seabed, for example due to damage from gill nets, and then pick up debris as they travel along the seabed with the currents. In addition to the direct damage from fishing, this study shows that ghost fishing may also be responsible for some sea fan mortality. Litter from fishing was the main source of material wrapped around the sea fangle samples that were collected around southwest England. The increased drag of rubbish accumulating around the live gorgonians would make them more vulnerable to removal from their anchorage to the sea floor, particularly during storms. Divers reported that fishing gear was wrapped around live gorgonians and gorgonian skeletal tissue was found here growing over plastic fishing line (Figure 5), which shows examples of when fans become entangled when they are still growing. 'Ghost fishing' usually describes the process whereby lost or abandoned gear continues to catch commercial species but it can also cause mortality in gorgonians (Matsuoka et al. 2005; Brown \& Macfadyen, 2007). Ghost fishing here also applies to lost domestic marine litter, as many household items were found wrapped around the Pink Sea Fans such as clothing, balloons and plastic.

216 The cumulative effects of lost fishing gear are an ever-growing problem since most modern 217 fishing gear is made of non-biodegradable plastic: materials such as monofilament netting 218 and polypropylene twine accumulate on the seafloor and this can damage long-lived sessile 
marine organisms (Brown \& Macfadyen, 2007; Bauer et al. 2008). Impacts can occur when large numbers of recreational anglers lose hook-and-line gear, as this can adversely affect the health and survival of sessile invertebrates causing tissue abrasion in gorgonians (Asoh et al. 2004; Chiappone et al. 2005; Lewin et al. 2006). Injury from tissue abrasion via monofilament line and other fishing gear causes infection and disease in tropical corals (Mydlarz et al. 2006).

224

225 Lamb et al. (2015) found four-fold higher levels of coral disease outside no-take marine reserves on the Great Barrier Reef that they attributed to the abundance of derelict fishing gear outside the reserves.

While fishing gear explains most of the sea fangle composition, there was a huge variety of marine debris from domestic sources. Reducing the amount of litter that enters the marine environment would be a valuable step towards mitigating damage to coral gardens. Further, following designation, investment should be directed towards activities to clean up MPAs of existing marine debris. "On the 2nd of October 2016 the UK prime minister pledged to leave the European Union by spring 2019, and that EU law will be transposed into domestic law, wherever practical" (BREXIT) (Jackson et al. 2016). Currently, The EU Marine Strategy Framework Directive outlines management steps required to improve the marine realm including that "Properties and quantities of marine litter do not cause harm to the coastal and marine environment" by 2020 (Council of the European Communities, 2008).

Fishing gear is the second largest source of beach litter washed ashore in the UK after public waste, with $106.2 \mathrm{~km}$ of fishing nets and net pieces picked up in voluntary clean-up operations in 2015 (Marine Conservation Society 2016). Such clean-up operations can be difficult and costly, for example the Korean Government funded projects to remove marine debris including beach clean ups, removing drifting debris from the sea surface, and then moving offshore and into the deep sea to remove derelict fishing gears (Cho, 2011) and in Hawaii divers have been employed to systematically remove derelict fishing gear (Donohue et al. 2001). This study highlights the importance of countries adhering to the EU MSFD marine litter guidance and demonstrates the need for more ambitious regulation which could be created if the UK re-write existing legislation following BREXIT. Beach clean-ups and citizen education can also contribute to stopping debris entering the seas, and fishing closures can be effective at reducing damage from both mobile and static gear, as well as reducing marine litter and promoting coral habitat recovery within the regeneration areas (Harter et al. 2009; Lamb et al. 2015).

\section{Acknowledgements}

We thank Will MacLennan, Dr Keith Hiscock and Chris Wood for providing underwater images, Steve Trewhella for his advice on sample collection, Plymouth University staff (Alex Fraser, Dr Stacey DeAmicis, and Dr Rebecca Ross) and student volunteers for their assistance with sea fangle dissections and Liam Faisey for collecting gorgonians from Wembury beach. We also thank Sarah Nancollas and Sophie Cousens for data collation and map production and Russell Taylor for the term sea fangle and the fantastic animation. 


\section{References}

Althaus F, Williams A, Schlacher TA, Kloser RJ, Green MA, Barker BA, Bax NJ, Brodie P, Schlacher-Hoenlinger MA. 2009. Impacts of bottom trawling on deep-coral ecosystems of sea mounts are long-lasting. Marine Ecology Progress Series 397: 279-294.

Anderson MJ. 2001. A new method for non-parametric multivariate analysis of variance. Austral Ecology 26: 32-46.

Asoh K, Yoshikawa T, Kosaki R, Marschall EA. 2004. Damage to cauliflower coral by monofilament fishing lines in Hawaii. Conservation Biology 18: 1645-1650.

Auster PJ, Kilgour M, Packer D, Waller R, Auscavitch S, Watling L. 2013. Octocoral gardens in the Gulf of Maine (NW Atlantic). Biodiversity 14: 193-194

Bauer LJ, Kendall MS, Jeffrey CFG. 2008. Incidence of marine debris and its relationships with benthic features in Gray's Reef National Marine Sanctuary, Southeast USA. Marine Pollution Bulletin 56: 402-413.

Bo M, Bava S, Canese S, Angiolillo M, Cattaneo-Vietti R, Bavestrello G. 2014. Fishing impact on deep Mediterranean rocky habitats as revealed by ROV investigation. Biological Conservation 171: 167-176.

Brown J, Macfadyen G. 2007. Ghost fishing in European waters: impacts and management responses. Marine Policy 31: 488-504.

Campbell MS, Stehfest KM, Votier SC, Hall-Spencer JM. 2014. Mapping fisheries for marine spatial planning: Gear-specific Vessel Monitoring System (VMS), marine conservation and offshore renewable energy. Marine Policy 45: 293-300.

Cerrano C, Bavestrello G, Bianchi CN, Cattaneo-vietti R, Bava S, Morganti C, Morri C, Picco P, Sara G, Schiaparelli S, et al. 2000. A catastrophic mass-mortality episode of gorgonians and other organisms in the Ligurian Sea (NW Mediterranean), summer 1999. Ecology Letters 3: 284-293.

Chiappone M, Dienes H, Swanson DW, Miller SL. 2005. Impacts of lost fishing gear on coral reef sessile invertebrates in the Florida Keys National Marine Sanctuary. Biological Conservation 121: 221-230.

Cho DO. 2011. Removing derelict fishing gear from the deep seabed of the East Sea. Marine Policy 35: 610-614.

Clarke K, Warwick RM. 2001. Change in Marine Communities: an Approach to Statistical Analysis and Interpretation, 1st Edition edn. PRIMER-E, Plymouth, UK. 
Clark MR, Rowden AA, Schlacher T, Williams A, Consalvey M, Stocks KI, Rogers AD, O'Hara TD, White M, Shank TM, Hall-Spencer JM. 2010. The Ecology of Seamounts: Structure, Function, and Human Impacts. Annual Review of Marine Science 2: 253-278.

Coma R, Pola E, Ribes M, Zabala M (2004) Long-term assessment of temperate octocoral mortality patterns, protected vs. unprotected areas. Ecological Applications 14:1466-1478

Costello MJ, McCrea M, Freiwald A, Lundälv T, Jonsson L, Bett BJ, van Weering TC, de Haas H, Roberts JM, Allen D. 2005. Role of cold-water Lophelia pertusa coral reefs as fish habitat in the NE Atlantic. In Cold-water corals and ecosystems (pp. 771-805). Springer Berlin Heidelberg.

Council of the European Communities. 2008. Directive 2008/56/EC of the European Parliament and of the Council of 17 June 2008 establishing a framework for community action in the field of marine environmental policy (Marine Strategy Framework Directive). Official Journal of the European Communities L164: 19-40.

Donohue MJ, Boland RC, Sramek CM, Antonelis GA. 2001. Derelict fishing gear in the northwestern Hawaiian Islands: Diving surveys and debris removal in 1999 confirm threat to coral reef ecosystems. Marine Pollution Bulletin 42: 1301-1312.

Edinger EN, Wareham VE, Haedrich RL. 2007. Patterns of groundfish diversity and abundance in relation to deep-sea coral distributions in Newfoundland and Labrador waters. Bulletin of Marine Science 81: 101-122.

Eno NC, MacDonald DS, Kinnear JAM, Amos CS, Chapman CJ, Clark RA, Bunker F, Munroe C. 2001. Effects of crustacean traps on benthic fauna. ICES Journal of Marine Science 58: 11-20.

Gosse PH. 1860. A history of the British sea-anemones and corals. Van Voorst publishers, London.

Hall-Spencer JM, Allain V, Fosså JH. 2002. Trawling damage to Northeast Atlantic ancient coral reefs. Proceedings of the Royal Society London 269: 507-511.

Hall-Spencer JM, Pike J, Munn CB. 2007a. Diseases affect cold water corals too: Eunicella verrucosa (Cnidaria: Gorgonacea) necrosis in SW England. Diseases of Aquatic Organisms 76: 87-97.

Hall-Spencer JM, Rogers A, Davies J, Foggo A. 2007b. Historical deep-sea coral distribution on seamount, oceanic island and continental shelf-slope habitats in the NE Atlantic. Bulletin of Marine Science 81:135-146.

Hall-Spencer JM, Tasker M, Soffker M, Christiansen S, Rogers S, Campbell M, Hoydal K. 2009. Design of Marine Protected Areas on High Seas and territorial waters of Rockall Bank. Marine Ecology Progress Series 397: 305-308. 
Harter SL, Ribera MM, Shepard AN, Reed JK. 2009. Assessment of fish populations and habitat on Oculina Bank, a deep-sea coral marine protected area off eastern Florida. Fishery Bulletin 107: 195-206.

Hinz H, Tarrant D, Ridgeway A, Kaiser MJ, Hiddink JG. 2011. Effects of scallop dredging on temperate reef fauna. Marine Ecology Progress Series 432: 91-102.

IUCN. 2015. The IUCN Red List of Threatened Species. Version 2015-4.

Jackson EL, Cousens SL, Bridger DR, Nancollas SJ, Sheehan EV. 2016. Conservation inaction in action for Essex seagrass meadows? Regional Studies in Marine Science 8:141-150

Jackson EL, Davies AJ, Howell KL, Kershaw PJ, Hall-Spencer JM. 2014. Future-proofing marine protected area networks for cold water coral reefs. ICES Journal of Marine Science. 71(9): 2621-2629

Kim K. 2015. Diseases of octocorals. In Diseases of Coral, Woodley CM, Downs CA, Bruckner AW, Porter JW Galloway SB (eds). John Wiley \& Sons, Inc, Hoboken, NJ.

Koslow JA, Gowlett-Holmes K, Lowry JK, O'Hara TO, Poore GCB, Williams A. 2001. Seamount benthic macrofauna off southern Tasmania: community structure and impacts of trawling. Marine Ecology Progress Series 213: 111-125.

Krieger KJ, Wing BL. 2002. Megafauna associations with deepwater corals (Primnoa spp.) in the Gulf of Alaska. Hydrobiologia 3: 83-90.

Lamb JB, Williamson DH, Russ GR, Willis BL. 2015. Protected areas mitigate diseases of reefbuilding coral by reducing damage from fishing. Ecology 96: 2555-2567.

Lastras G, Canals M, Ballesteros E, Gili J-M, Sanchez-Vidal A. 2016. Cold-water corals and anthropogenic impacts in La Fonera submarine canyon head, northwestern Mediterranean Sea. PLoS ONE 11(5): e0155729. doi:10.1371/journal.pone.0155729

Le Danois E. 1948. Les Profondeurs de la Mer. Payot, Paris 303 pp.

Lewin WC, Arlinghaus R, Mehner T. 2006. Documented and potential biological impacts of recreational fishing: insights for management and conservation. Reviews in Fisheries Science 14: 305-367.

Marine Conservation Society. 2016. Great British Beach Clean 2015 Report. Marine Conservation Society, UK.

Matsuoka T, Nakasima T, Nagassawa N. 2005. A review of ghost fishing: scientific approaches to evaluation and solutions. Fisheries Science 71: 691-702. 

of fisheries on deep-water gorgonian corals in the Northeast Channel, Nova Scotia (Canada). American Fisheries Society Symposium 41: 369-382.

Mydlarz LD, Jones LE, Harvell CD. 2006. Innate immunity, environmental drivers, and disease ecology of marine and freshwater invertebrates. Annual Review of Ecology, Evolution, and Systematics 37: 251-288.

366

367

368

369

370

371

372

373

374

375

376

377

378

379

380

381

382

383

384

385

386

387

388

389

390

391

392

393

394

Pikesley SK, Godley BJ, Latham H, Richardson PB, Robson LM, Solandt JL, Trundle C, Wood C, Witt MJ. 2016. Pink Sea Fans (Eunicella verrucosa) as indicators of the spatial efficacy of Marine Protected Areas in southwest UK coastal waters. Marine Policy 64: 38-45.

Ponti M, Grech D, Mori, M, Perlini RA, VentraV, Panzalis PA, Cerrano C. 2016. The role of gorgonians on the diversity of vagile benthic fauna in Mediterranean rocky habitats. Marine Biology 163: 120.

Rijnsdorp AD, Bastardie F, Bolam SG, Mortensen LB, Eigaard OR, Hamon KG, Hiddink JG, Hintzen NT, Ivanović A, Kenny A, et al. 2016. Towards a framework for the quantitative assessment of trawling impact on the seabed and benthic ecosystem. ICES Journal of Marine Science 73: 27-38.

Roberts JM, Davies AJ, Henry LA, Dodds LA, Duineveld GCA, Lavaleye MSS, Maier C, van Soest RWM, Bergman MJN, Hühnerbach V, et al. 2009. Mingulay reef complex: an interdisciplinary study of cold-water coral habitat, hydrography and biodiversity. Marine Ecology Progress Series 397: 139-151.

Russ G. 1991. Coral reef fisheries: effects and yields. In The ecology of fishes on coral reefs, Sale PF (ed). Academic Press, San Diego, California; 601-635.

Sheehan EV, Stevens TF, Gall SC, Cousens SL, Attrill MJ. 2013a. Recovery of a temperate reef assemblage in a Marine Protected Area following the exclusion of towed demersal fishing. PLoS One 8(12): e83883.

Sheehan EV, Cousens SL, Nancollas SJ, Stauss C, Royle J, Attrill MJ. 2013b. Drawing lines at the sand: Evidence for functional vs. visual reef boundaries in temperate Marine Protected Areas. Marine pollution bulletin 76(1): 194-202.

Söffker M, Sloman KA, Hall-Spencer JM. 2011. In situ observations of fish associated with coral reefs off Ireland. Deep Sea Research Part I: Oceanographic Research Papers 58: 818-825.

Stone RP. 2006. Coral habitat in the Aleutian Islands of Alaska: depth distribution, fine-scale species associations, and fisheries interactions. Coral Reefs 25: 229-238.

Watling L, Norse EA. 1998. Disturbance of the seabed by mobile fishing gear: a comparison to forest clearcutting. Conservation Biology 12: 1180-1197. 
395 Witherell D, Coon C. 2000. Protecting gorgonian corals off Alaska from fishing impacts. In First 396 international symposium on deep-sea corals, Willison JHM, Hall J, Gass SE, Kenchington ELR, 397 Butler M, Doherty P (eds). Ecology Action Center and Nova Scotia Museum, Halifax; 117-125.

398 Wood C. 2013. Sea anemones and corals of Britain and Ireland. Wild Nature Press, Plymouth, $399160 \mathrm{pp}$.

400 Yesson C, Taylor ML, Tittensor DP, Davies AJ, Guinotte J, Baco A, Black J, Hall-Spencer JM, 401 Rogers AD. 2012. Global habitat suitability of cold-water octocorals. Journal of Biogeography 402 39: 1278-1292

403

\section{Tables}

405 Table 1. a) Results of PERMANOVA to compare the amount ( $\mathrm{Lmm}$ ) of the debris Source 406 (Fishing or Domestic) between Location (Chesil Beach, Wembury or Newquay) b) Pairwise test 407 between Source at each Location. Bold types denotes a statistically significant result

\begin{tabular}{lllllllll}
\hline a) Factor & DF & SS & MS & F & P & b) Pairwise & T & P \\
\hline Source (So) & 1 & $9.58 \mathrm{E}+06$ & $9.58 \mathrm{E}+06$ & 47.62 & $\mathbf{0 . 0 0 0 1}$ & Chesil Beach & 2.63 & $\mathbf{0 . 0 0 0 1}$ \\
Location & 2 & $2.43 \mathrm{E}+06$ & $1.22 \mathrm{E}+06$ & 6.04 & $\mathbf{0 . 0 0 4}$ & Wembury & 2.19 & $\mathbf{0 . 0 0 4}$ \\
$\begin{array}{l}\text { (Lo) } \\
\text { So } x \text { Lo }\end{array}$ & 2 & $2.02 \mathrm{E}+06$ & $1.01 \mathrm{E}+06$ & 5.02 & $\mathbf{0 . 0 0 9}$ & Newquay & 5.32 & $\mathbf{0 . 0 0 0 1}$ \\
Residual & 68 & $1.37 \mathrm{E}+06$ & $2.01 \mathrm{E}+05$ & & & & & \\
Total & 73 & $2.77 \mathrm{E}+06$ & & & & & & \\
\hline
\end{tabular}

408

409

410 
412
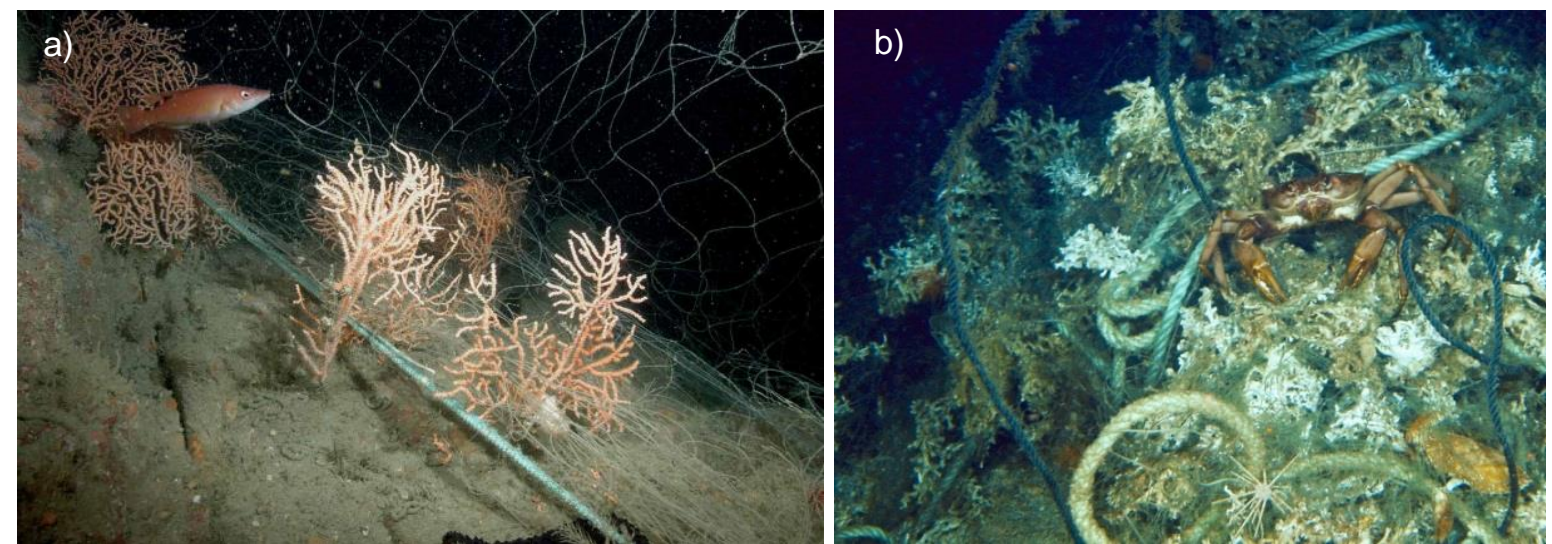

Figure 1. a) Bottom set monofilament plastic gillnet running through a Eunicella verrucosa

414 coral garden on bedrock at 20 m depth off Plymouth, southwest England with a female 415 cuckoo wrasse Labrus mixtus top left (photo courtesy of Keith Hiscock) and b) a reef 416 constructed by scleractinian and stylasterid corals damaged by non-biodegradable lost 417 fishing gear at $1000 \mathrm{~m}$ depth off southwest Ireland with a crab (Chaceon sp.) feeding on 418 invertebrates within the smashed-up reef (photo taken by IFREMER owned ROV Victor 2000 419 aboard RV Polarstern during a study by Söffker et al. 2011).

420

421

422

423

424

425

426

427

428

429

430

431

432 


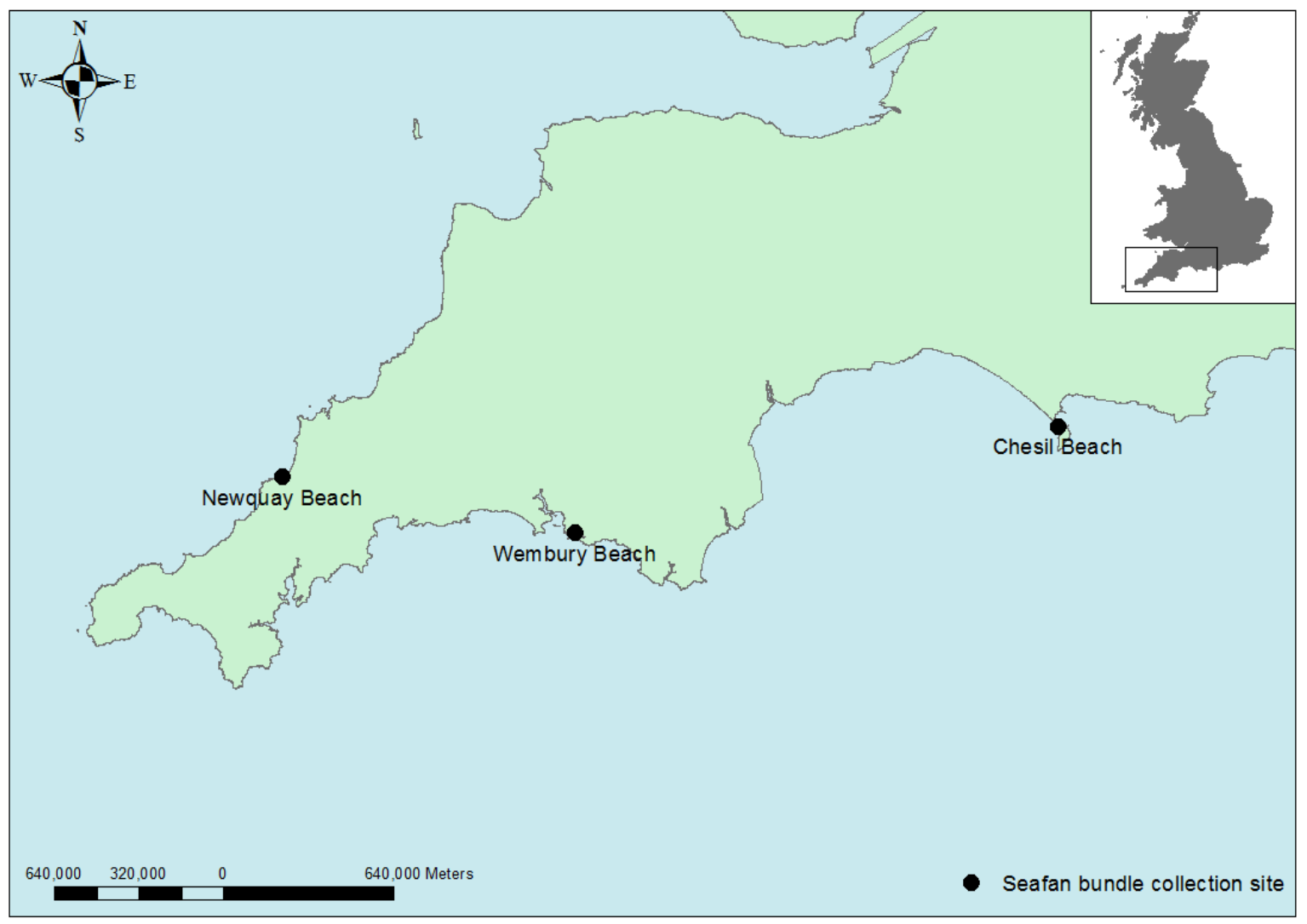

436 Figure 2. Strandline survey sites at Chesil Beach, Wembury and Newquay in southwest 437 England.

438

439

440

441

442

443

444

445

446 
448
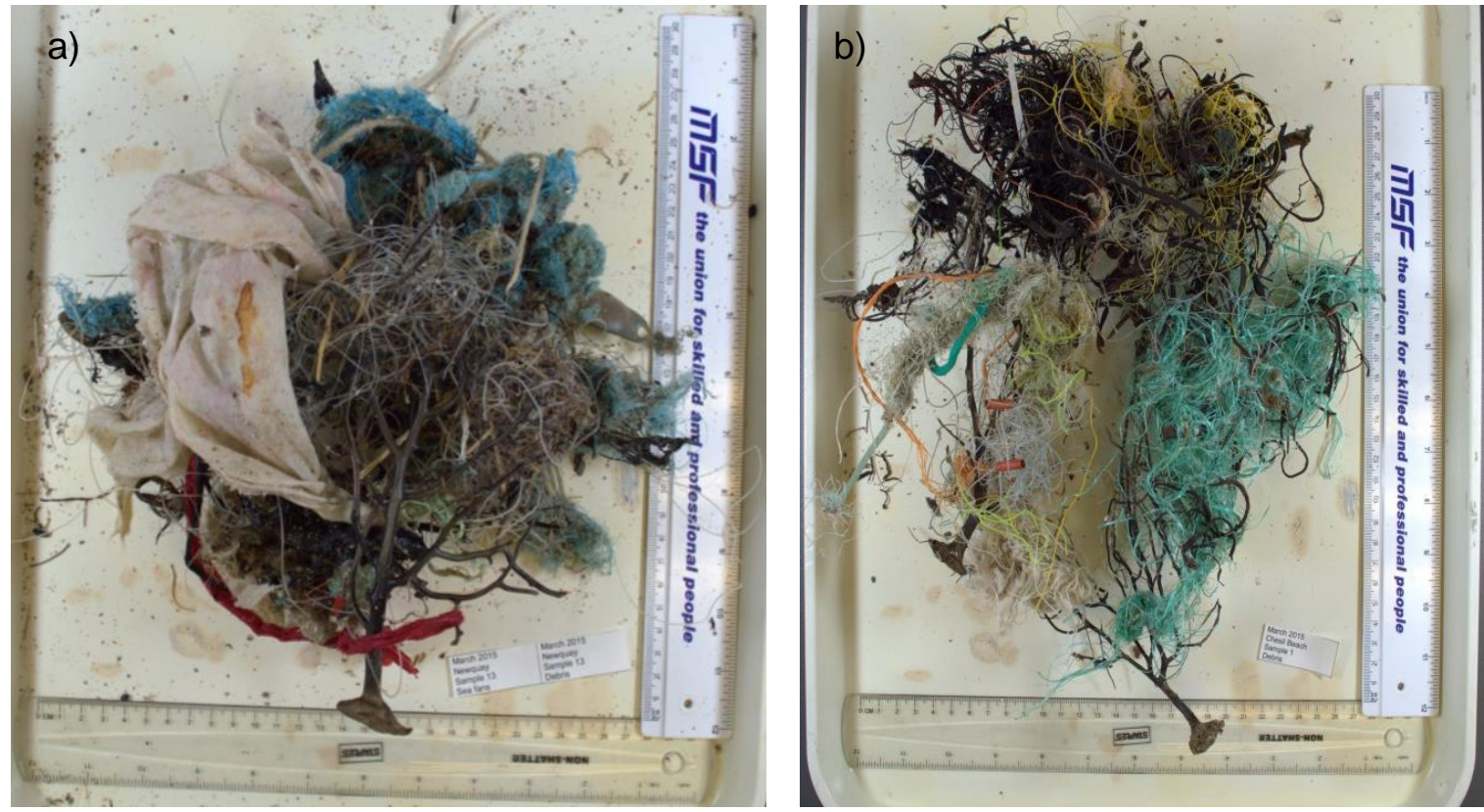

449

450

451

452

453

454

455

456

458

459

460

461

462

463

464

465

466

467

468

469

470

471

472

473

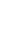

(1)

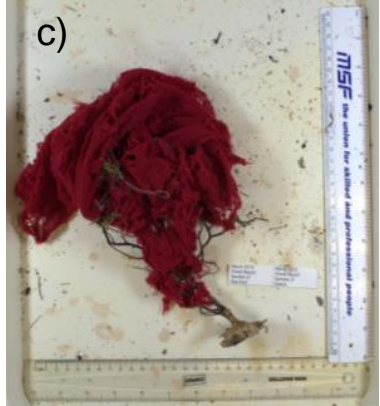

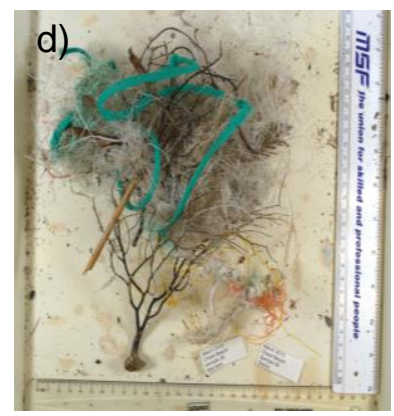

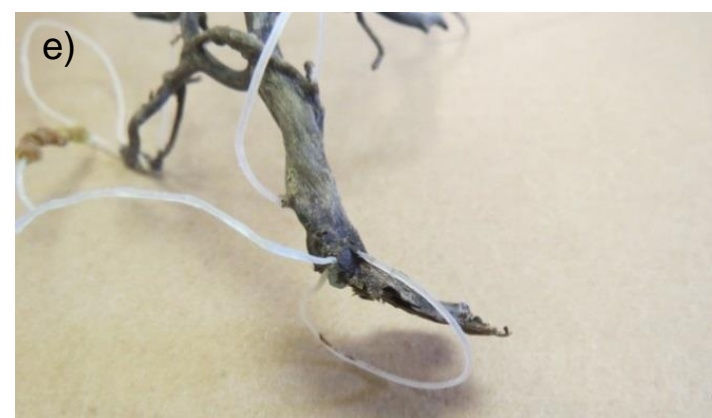

Figure 3a-e) Variety of sea fangles (marine debris wrapped around Eunicella verrucosa analysed in the laboratory (rulers $30 \mathrm{~cm}$ long). b) monofilament line overgrown by the gorgonian skeleton of $E$. verrucosa, collected from Chesil Beach in January 2015. 


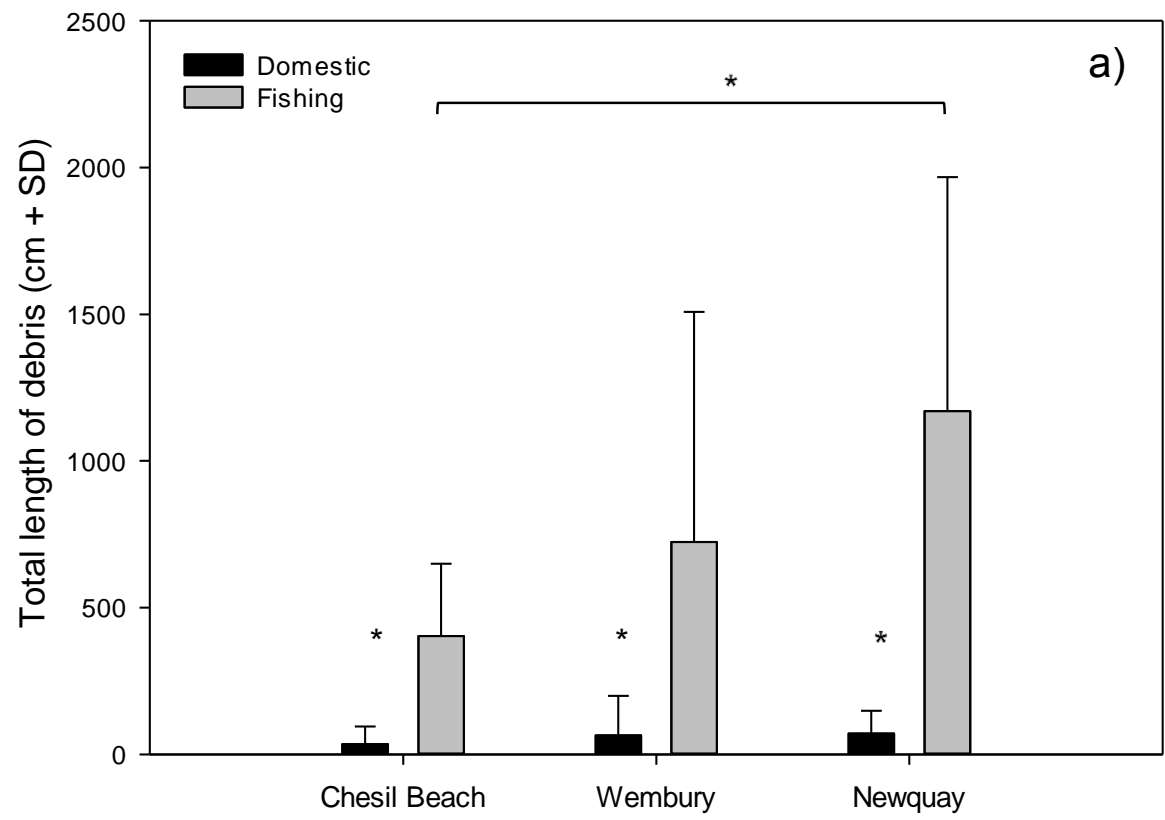

485

486

487

488

489

490

491

492

493

494

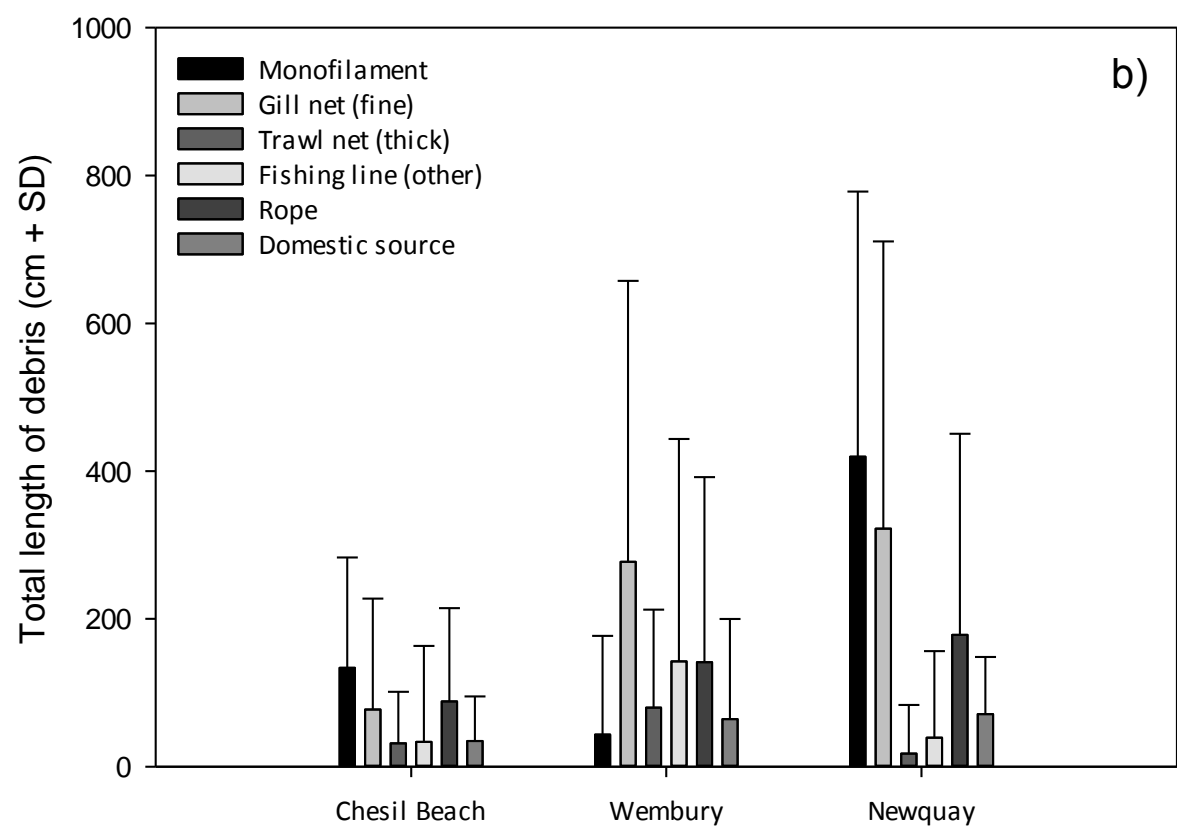

496 Figure 4 a) Total length ( $\mathrm{cm}+\mathrm{SD}$ ) of fishing and domestic debris per sea fangle sampled at 497 three locations around southwest England (Chesil Beach, Wembury and Newquay).

$498 *$ denotes statistically significant difference. b) Total length ( $\mathrm{cm}+\mathrm{SD}$ ) of different types of 499 fishing gear and domestic debris per sea fangle. 

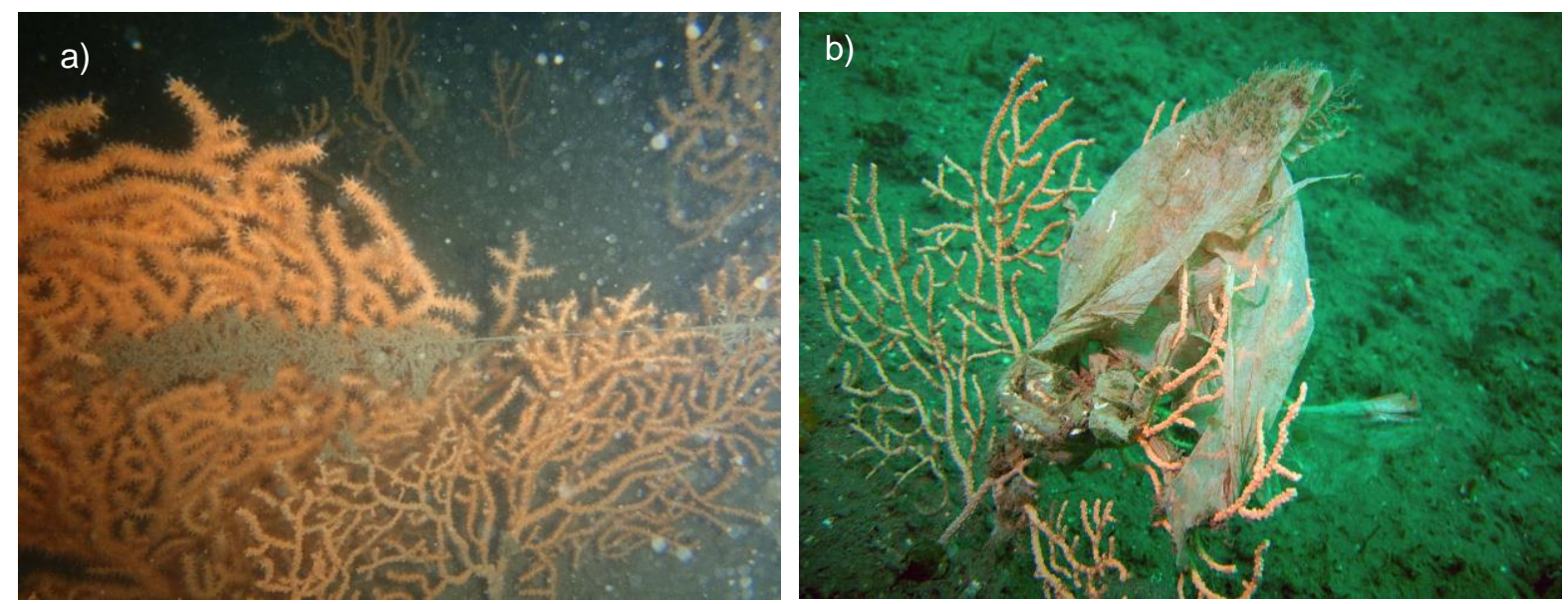

504

505 Figure 5a) Fishing line caught on living Eunicella verrucosa colonies forming a coral garden 506 habitat on silty rocks (Photo courtesy of William MacLennan, 2014) and b) a living $E$.

507 verrucosa wrapped in a plastic bag (Photo courtesy of Chris Wood/Seasearch, 2007), both 508 images recorded at $24 \mathrm{~m}$ depth in Lyme Bay (off Chesil Beach site) in southwest England. 509

510

511

512

513

514

515

516 


\section{Supporting information}

Table S1. Metrics recorded for Eunicella verrucosa individuals found within sea fangles collected at three sites around southwest England in January and February 2015.

\begin{tabular}{|c|c|c|c|c|c|c|c|c|c|c|c|c|}
\hline \multirow{2}{*}{$\begin{array}{l}\text { Sea fangle collection site } \\
\text { (number collected) }\end{array}$} & \multicolumn{4}{|c|}{ Chesil Beach $(n=30)$} & \multicolumn{4}{|c|}{ Wembury ( $n=15)$} & \multicolumn{4}{|c|}{ Newquay $(n=30)$} \\
\hline & Mean & SD & Max & Min & Mean & SD & Max & Min & Mean & SD & Max & Min \\
\hline Weight of sea fangle (g) & 100.5 & 80.8 & 310.7 & 12.2 & 204.8 & 236.3 & 819.2 & 12.4 & 176.8 & 170.5 & 680.4 & 15.0 \\
\hline Weight of all seafans (g) & 18.1 & 17.8 & 73.5 & 0.9 & 34.2 & 39.0 & 145.0 & 1.3 & 22.0 & 23.3 & 114.6 & 0.8 \\
\hline Length of sea fangle (cm) & 37.4 & 15.4 & 76.0 & 12.0 & 36.4 & 18.4 & 77.5 & 15.0 & 29.2 & 15.2 & 72.0 & 10.0 \\
\hline Width of sea fangle $(\mathrm{cm})$ & 18.9 & 7.6 & 43.0 & 6.0 & 19.6 & 4.6 & 27.5 & 13.9 & 18.9 & 7.9 & 35.0 & 7.5 \\
\hline Central seafan Height (cm) & 16.1 & 3.9 & 27.2 & 10.0 & 14.0 & 4.7 & 26.0 & 8.4 & 15.3 & 16.2 & 15.0 & 7.5 \\
\hline Central seafan Width $(\mathrm{cm})$ & 10.7 & 4.2 & 18.0 & 2.0 & 10.8 & 4.3 & 19.0 & 5.8 & 10.9 & 6.9 & 40.0 & 3.1 \\
\hline $\begin{array}{l}\text { Number of fans on periphery } \\
\text { (with holdfasts) }\end{array}$ & 3.1 & 3.9 & 16.0 & 0.0 & 6.1 & 7.6 & 26.0 & 0.0 & 2.4 & 2.9 & 13.0 & 0.0 \\
\hline (without holdfasts) & 1.9 & 2.2 & 10.0 & 0.0 & 10.8 & 11.3 & 37.0 & 0.0 & 6.7 & 8.9 & 46.0 & 0.0 \\
\hline
\end{tabular}

